\title{
EMPLOYING HIGHLY SKILLED PROFESSIONALS IN MULTINATIONAL CORPORATIONS
}

\section{ZAM'nSTNÁ VÁNÍ VYSOCE KVALIFIKOVANÝCH PRACOVNÍKŠ V NADNÁRODNÍCH SPOLELNOSTECH}

\section{ING. RENATA LUHLOVÁ, BA (HONS)}

\author{
\begin{tabular}{l|l} 
Katedra marketingu a obchodu & Department of Marketing and Business
\end{tabular} \\ Ekonomická fakulta Faculty of Economics \\ Technická univerzita v Liberci Technical University in Liberec \\ $\triangle$ Studentská 2, 41617 Liberec, Czech Republic \\ E-mail: renata.cuhlova@tul.cz
}

\begin{abstract}
Annotation
Competitiveness of companies is becoming increasingly depending on persons and the method of their management. This has occurred especially during the last century when economic globalization has led to integration of regions into economic areas and strong internationalization of labour market. Multinational corporations (MNCs) operating on different worldôs markets and employing personnel coming from various countries are important parts of the process. The paper supports the phenomenon with evidence of increased share of foreigners in management positions in the notable Czech companies. A speed of migration procedure is an important factor influencing a decision of MNCs about investment in particular countries. The government of the Czech Republic is aware of this fact and therefore aims to gain a competitive advantage over other states through creation effective tools supporting migration of highly skilled workers. The paper presents an overview of Czech migration measures directed at highly skilled foreigners.
\end{abstract}

Key words

migration policy, multinational corporations, labour market, highly skilled professionals

\section{Anotace}

Konkurenceschopnost podnik丁 se stává İ ím dál více závislou na lidech a zp Tsobu jejich Sízení, zvláğ门 potom błhem posledního století, kdy vlivem ekonomické globalizace dochází $k$ integraci region丁 $v$ hospodáŚsé oblasti a $k$ výrazné internacionalizaci trhu práce. DJleǵitým I initelem tohoto procesu

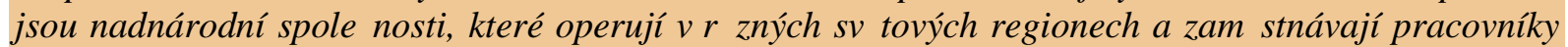
pocházející z jiných zemí. PŚsp円jek tento fenomén dokládá na rostoucím podílu cizinc 丁 ve vedení významných !eských podnik丁. Pro nadnárodní firmy je rychlost migraḷi procedury dTleǵitým faktorem, který se podílí na rozhodnutí o investování v jednotlivých státech. Tuto skutel nost si vláda Leské republiky uv hlomuje, a proto se pomocí tvorby efektivních nástroj丁 na podporu migrace vysoce kvalifikovaných pracovník丁 snağ získat konkuren!̣i výhodu nad ostatními zem円ni. PŚsp円ek uvádí pŚshled ḷ eských migra!̣ ních opat Śní ur! ených pro vysoce kvalifikované cizince.

\section{Klị ová slova}

migra! ní politika, nadnárodní firmy, trh práce, vysoce kvalifikovaní pracovníci

JEL classification: J61, 015

\section{Introduction}

The Czech economy has opened itself towards the outside world in 1989 and by entry into the European Union in 2004 even confirmed its openness. Nowadays, the Czech Republic plays a part in the global economy and deals with globalization world trends and internationalization of market as 
other developed economies. The international competitive environment is rapidly changing and its impact on national companies as well as whole economies is becoming stronger.

Multinational corporations (MNCs) have become an important driving factor of work environmentô internationalization and the main centres of economic power. These companies with facilities in one or more countries other than the home country of the headquarter (HQ) are capable of effective using sources and assets of single national economies; efficient transferring capital, technologies, human resources and last but not least adapting organisational, marketing and financial strategies to the new circumstances of business environment. A choice of HQôstrategy is affected by a whole range of factors; undoubtedly one being is a migration policy of individual countries. Effective migration tools bring foreign investors and skilled labour to the country which both means a long lasting benefit for the country.

\section{Human resource management in international environment}

Companies operating in the international environment choose a model of their organizational culture and a degree of national cultureôs influence on strategies and decision rules of the firm. Perlmutter (1969) defines three international attitudes known as the EPG framework; ethnocentric, polycentric and geocentric. Lately, the idea has been expanded by the fourth dimension of regiocentric orientation in the international operationsôevolution (Heenan, Perlmutter 1979). These approaches determine the relationship between organizational strategy and human resource policies during filling the key vacancies in subsidiaries of MNCs. It represents the foreign companiesôway of expanding abroad and transferring employees and human resource management activities.

Ethnocentric orientation defines companies orientated towards home country. A typical feature of these organizations is filling the key positions (jobs in the executive, senior positions and positions of specialists) in all subsidiaries by expatriates sent from the HQ. This strategy is typical for companies that expand to a new market and they have a lack of information regarding to local labour situation. Increasing number of companies, also from financial reasons, applies a policy of localization; a training and development of local employees with a target to fill the key positions by them. A view of polycentric alias host country oriented state of mind represents another possible orientation and illustrates easier dealing of local persons since they do not have to become adapted to a new culture, they are acquainted with that. Developing local professionals for the key positions in their own country is the basis of management there. The attitude is welcomed between all local employees however job promotion is limited only within the subsidiary. Polycentric approach is usually in regions with very diverse culture. The subsidiaries have to adapt to the local conditions and the HQ encourages some level of subsidiariesôautonomy. Application of unified organizational culture could be problematic and therefore plurality and subcultures are present there. The autonomy of subsidiaries together with common underestimation of language and cultural barriers between the subsidiary and the HQ brings issues in mutual coordination. This may lead up to notional disintegration of MNCs in several independent national units more loyal to their home country rather than to the employer in the HQ. Potential of international environmentôs synergy is not fully utilized. Geocentric (transnational) strategy is oriented towards the whole world. By influencing of the HQôterritory linked up with national standards of foreign subsidiaries, cultures are more brought together and individual specifics are better utilized. Regional parts of the international company work effectively and create synergy. Implementation of organizational culture of this kind is neither short-term nor effortless. The key positions in the whole company are filled by the best people based on their work competences and job results without regard to the country of origin. Employees are required to have experiences with working in multicultural environment in order to be capable of completing tasks in various regions of the world. As Tureckiová (2004) points out, despite mentioned difficulties, more organizations select this strategy. Regiocentric strategy is the fourth approach of international companies and it completes the framework EPG. This orientation belongs within the polycentric and the regiocentric strategy and in this case, international human resources are managed according to geographic areas or set regions. Mobility of employees is going on within these regions that are usually stated by natural borders, such as a region of Europe, South America, and Middle East. 
Framework EPRG explains a principle of international human resource managementô function. It is usually a combination of strategies mentioned above in practice and the choice and application depends on particular situation (e.g. opening new branch, companyôs aims, political instability) in specific region. According to Perlmutterô research (1969) international companies usually go through all these types of orientation, starting with the ethnocentric sight and reaching the geocentric one.

\section{Types of Staffing Strategy}

International human resource management in MNCs involves employees from three country types. There is a home country where is the companyôheadquarters, a host country where subsidiaries are allocated and another third country that also provides human resources (Scullion, Collings 2006). According to this classification, a company can employ parent country nations (PCNs), host country nations (HCNs) and third country nations (TCNs). The chosen management strategy of a foreign subsidiary influences where the company prefers its employees from. Each of the options has its advantages and disadvantages for the company. PCNs send out from country of the HQ and TCNs are usually minority of all employees. Although their recruitment is linked with substantially higher expenses, they are the source that is very valuable and their management is the most demanding.

PCNs or so called expatriates are skilled workers sent abroad by their HQ to a foreign subsidiary. Besides the role during entering into new markets and transferring know-how of the company since they are cognizant of aims, policies and practices of the HQ, the expatriate operates as an agent of the HQ in terms of direct control, establishing contacts and communication network between the HQ and the subsidiary, simplification of mergers and acquisitions. Common dominance of PCNs in the Czech Republic had been especially in the time of economic transformation in the first half of 90 s when there was a lack of professionals with experiences of Western way of doing business (DvoŚḱková et al. 2012). The term ñthe third country nationò refers to employee that is not from the HQôcountry and not even from the country where he is going to work, he can therefore utilize the perspective of a foreigner (Collings et al. 2010). Hiring these professionals is usually less costly and assimilation is easier since TCNs commonly come from the same region where a subsidiary is allocated and therefore the persons are aware of local cultural customs and business manners. Adaptability and willingness to global mobility is their big asset. TCNs as international managers often create multicultural teams proving a companyô aim to operate in global scale with competent and skilled professionals. During decision about TCNsôpositioning, it is necessary to consider bad acceptance of certain nationality as a companyố representation in specific social system. It may be a historical enmity between some national groups or an unacceptability of women that occurs on some job positions, in the Japanese social system or in the Arabic world due to still existing religious gender prejudices (DvoŚíková et al. 2012). Inpatriates are another option of staffing in the international environment and the term describes people from subsidiaries transferred to the HQ for some period of time for the purpose of understanding firmôs aims, organizational culture and developing network. A benefit from inpatriation is not only creation of link between the HQ and the subsidiary for cooperation but also gaining the multicultural perspective (Collings et al. 2010).

\section{Impacts of employing highly skilled foreigners}

Previous text shows that MNCs are the noticeable factor influencing migration of highly qualified workers. Moreover, their growing flow has become interest and present topic for many countries. As Lowell and Findlay (2001) emphasize, the existence of certain level of highly skilled mobility is a necessary condition for business expansion and creation of MNCs (so called ñbrain globalisationò).

As potential global effects of highly skilled migration are possible consider the following (Regets 2007):

- improvement of international flow of information (ñbrain exchangesò),

- more effective job match through global job search,

- greater employment options for professionals and researchers, 
- greater ability of employers to find unique skills sets,

- formation of international research and technological clusters,

- development and increase of technologies and know-how that would be more difficult to reach in individualôs level.

Feedback effects of international highly skilled migration persons must be deeper considered in a country-level for both the sending and receiving countries. Due to transition to the knowledge economy, the competitiveness is not possible to achieve without high quality of human resources anymore. An effort to attract highly skilled workers is becoming a part of national economic strategies and an object of competitive fight. However, it does not influence only immigration policy but also educational programs, research funding, international investments, tax policy. It is important to realize that positions of local workers are linked to positions of skilled foreigners. Availability of new qualified people increases opportunities of R\&D and overall economic activities for the host country however the competition for local economically active population is higher. A loss of highly skilled labour explains a problem called ñbrain drainò The outflow of brains is considered for a form of work migration and brain drain is understood as a cross border movement of highly educated personnel staying abroad for longer time (IOM 2003). According to this concept, a level of education is the only standard for differentiating the outflow of brains from migration of workers and the main difference between these two groups is their ownership of university diploma. Despite often tendency to equate brain drain with emigration from developing countries, it is also an issue of many developed countries. An opposite term ñbrain gainñ is used in a context of developed countries and it explains a situation when the economy advantageously gains qualified human capital without any investments in workerô education. Yet, the brain gain is possible to understand also in terms of developing country, namely when outflow of skilled persons brings positive effects in long term. These impacts happen through creation of transnational business and scientific networks to facilitate contacts and knowledge transfer and through value of remittances to relatives and institutions in their home countries. Remittances exceed official development assistance and together with foreign direct investment, are the largest sources of external funding for these countries (Buch, Kuckulenz 2010). According to data from the World Bank (2014), remittances to developing countries are estimated at \$404 billion in 2013.

\section{Definition of highly skilled professionals}

Speed of migration process of potential employees is an important factor affecting a strategy of filling job positions in a foreign subsidiary of MNCs in a role of employer. Classification of applicants is a crucial factor in these procedures. There is no agreed definition of highly qualified workers at international level and as a result, the term ñskilledò is often interpreted in terms of completing tertiary education or its equivalent; however required knowledge and proficiency is also possible to acquire by experiences and practice. Definition is therefore based on educational attainment and work placement (Salt 1997). Science and technology is the only field where unified definition of highly skilled persons has been established. The concept ñHuman Resources in Science and Technologyò is used by OECD, Eurostat and therefore also Czech Statistical Office (Zaletel 2006). In the Czech Republic, the expertise is considered according to classification CZ-ISCO, formerly classification KZAM, in terms of education. The most common fields are: IT, healthcare, education, business and research and development. Table 1 shows an overview of elemental specification of highly skilled personnel. 
Tab. 1: Basic specification of highly skilled personnel

\begin{tabular}{|c|c|c|}
\hline Criterion & Classification & Specification \\
\hline Work placement & $\begin{array}{l}\text { ISCO - The International } \\
\text { Standard Classification of } \\
\text { Occupations }\end{array}$ & $\begin{array}{l}\text { ISCO } 1 \text { ï Legislators, senior officials and } \\
\text { managers } \\
\text { ISCO } 2 \text { ï Professionals } \\
\text { ISCO } 3 \text { ï Technicians and associate } \\
\text { professionals }\end{array}$ \\
\hline Educational attainment & $\begin{array}{l}\text { ISCED - The International } \\
\text { Standard Classification of } \\
\text { Education }\end{array}$ & $\begin{array}{l}\text { ISCED } 4 \ddot{i} \\
\text { Post-secondary non-tertiary education } \\
\text { ISCED } 5 \ddot{i} \text { First stage of tertiary education }{ }^{1} \\
\text { ISCED } 6 \ddot{i} \text { Second stage of tertiary education }{ }^{2}\end{array}$ \\
\hline
\end{tabular}

Another issue related to the labour flow is that no international system for recording skilled emigration exists (OECD 1996). More detailed view of the first class by professional classification CZ-ISCO with senior officers and managers can be found in Table 2 demonstrating the overall share of foreigners in management of the most current Czech notable companies also called as the Czech TOP 100. These data provided by Deloitte Corporate Governance Centrum (2013) report that their share has increased from a fifth to a quarter for the last ten years. Positions of foreign managers in supervisory board and statutory organs have strengthened. The largest difference is recorded in numbers of foreigners between boards of directorsômembers, from $18.6 \%$ of foreigners in 2003 up to $24.8 \%$ foreigners in 2013. This fact can be explained by increased number of companies rank among the Czech TOP 100 controlled by foreign capital and proprietors from abroad. Although the share of foreigners in statutory and supervisory boards of companies rises, opposite tendency can be observed on executive directorsô positions. Their share decreased from $2003(48.8 \%)$ by three percentage points $(45.6 \%)$.

Tab. 2: Share of foreigners in management of the Czech TOP 100 companies

\begin{tabular}{|l|c|c|}
\hline Czech Top 100 & Share of foreigners 2003 & Share of foreigners 2013 \\
\hline Members of board of directors & $18.6 \%$ & $24.8 \%$ \\
\hline Executive directors & $48.8 \%$ & $45.6 \%$ \\
\hline Statutory organs total & $21.5 \%$ & $29.1 \%$ \\
\hline Members of supervisory boards & $20.0 \%$ & $24.9 \%$ \\
\hline Total & $20.7 \%$ & $27.0 \%$ \\
\hline \multicolumn{2}{|c|}{ Source: Deloitte Corporate Governance Centrum Czech Republic 2013 }
\end{tabular}

\section{Migration policies and practices in the Czech Republic}

Migration policies aiming to attract foreign highly skilled professionals to the Czech Republic are exclusively focused on foreigners from the third countries. In consideration of membership of the Czech Republic in the European Union, inhabitants from the EU, EHP and Switzerland have almost the same position as Czech inhabitants and they have free movement permission for the Czech labour market.

In 2009, two projects supporting legal immigration of highly skilled labour, on a level of special residence mode, were launched. The government announced its own version of the Green Card for immigrants outside the EU with qualification demanded in the Czech Republic. It has a dual nature which means that combines work and residence permits in one document. The project should facilitate flexible recruitment of professionals from abroad and decrease administration for employer as well as applicant in the same time. There are three types of permits granted through the Green Card Programme and the Type A is intended for university degree holding applicants. Original list of 12 countries for green cards type A had been extended up to 64 countries (MVLT 2012). Blue Card,

\footnotetext{
${ }^{1}$ Programmes providing qualifications for gaining entry into advanced research programmes and professions with high skill requirements (e.g. medicine) and programmes designed to permit the acquisition of the practical skills and know-how for employment in a particular occupation but do not provide direct access to advanced research programmes.

2 Tertiary studies that lead to an advanced research qualification. They typically require the submission of a thesis or dissertation of publishable quality which is the product of original research (e.g. Ph.D.)
} 
established by a directive from the European Commission and inspired by practices in USA, Canada and Australia, has the similar approach. Until the end of 2012, 415 green cards were issued (Valenta 2013). In future, green cards should be replaced by employee cards that are going to be another step in order to make migration procedures in entering Czech labour market easier. Their main asset will be based on a single application for a work and residence permit in one time instead of individual applications in present. The draft amendment is expected to come into effect in 2014. Since 2012, the project Fast Track concerning to the transfer of executives, managers and specialists from established companies with international influence to the Czech Republic has been launched. No existence of sufficient legislation that would respond to the current need of foreign employers has been a reason for establishment of the project. The program provides more streamlined application process for work permits of persons coming to the Czech Republic within intra-company transfer from outside the EU. Foreign firms benefit from cost reduction joined to the expansion to the Czech Republic (CzechInvest 2012). During the first year of this project, 54 applications were taken care of (Valenta 2013). Another Czech project to speed up the process for the key foreign skilled workers is called the Welcome Package. The packageôs target group are statutory directors of newly established companies or companies already operating in the Czech Republic, upper level management members and key specialists who might be temporarily transferred by their parent companies for purpose of developing local business or training local employees. Since 2013 when the procedure has been launched, it focuses on effective launching process of foreign companies that choose a presence of PCNs for the early stage in newly established subsidiaries. Afterwards, job positions are in final phase designed for local human resources which the government takes into account. The main benefits of these projects are following (CzechInvest 2013):

- creating job positions and reducing unemployment,

- regional development, increasing qualification in regions,

- promotion of the Czech Republic as a country where foreign investors are welcomed,

- positive references from already established companies in relation to investors,

- preliminary verification of legislation prepared by EU in a field of economic migration,

- gaining competitive advantage compared to other countries in acquisition of investors, faster know-how transfer and building new positions on the market.

Migration projects mentioned above are still ongoing. The Proposition of Active Selection of a Qualified Foreign Labour Force was a project lasting from 2003 until 2010 based on the Quebec Certificate of Selection points system. It was the first try of the Czech Republic to attract highly skilled immigrants for permanent settlement and the aim was to bring qualified educated migrants that want to settle down in the country and to help them and their families to integrate into the Czech society. Total number of participants was 1806 foreign applicants and ca 1700 their family members (Veselá 2010).

\section{Conclusion}

International migration of skilled persons has assumed increased importance in recent years reflecting the impact of globalisation and multinational corporations. As the World Bank (2014) points out, when persons are able to move to where they are more productive, migration results in an increase of the world incomes. International companies have an important impact on the labour market in the Czech Republic that is more internationalized by their presence. Highly qualified professionals come to hold management and director positions or as specialists and other key experts. The choice of the companyô strategy for a foreign subsidiaryôs establishment, the way of recruitment plan of skilled job positions and how cooperative a government $\hat{Q}$ migration policy is in the intended location affects final decision to (non)realize the investment and know-how transfer.

On the other hand, a possibility to gain highly skilled labour in time and needful place is integral part of global strategies. A number of countries have recently liberalized their policies for the admission of highly skilled workers and it has happened also in the Czech Republic. However, in this case we have to point out that these migration programs are still in the beginning of their development there and the majority of highly skilled persons coming to the Czech Republic are through international company's 
transfers or recruitments. There are still apparent barriers to entrance of highly skilled foreigners that are not going to take job positions to the Czech inhabitants. Nevertheless, the proper common policy would increase the Czech Republic's attractiveness for the highly skilled persons.

\section{Literature}

[1] BUCH, C. M., KUCKULENZ, A., (2010). Worker Remittances and Capital Flows to Developing Countries. International Migration, vol. 48, iss. 5, pp. 89-117. DOI 10.1111/j.1468-2435.2009.00543.x.

[2] CzechInvest, (2012). Projekt ĂFast Trackñ. [online]. [cit. 2014-03-28]. Dostupné z: http://www.czechinvest.org/data/files/zrychlena-procedura-pro-vnitropodnikovu-prevadune-alokalizovane-zamustnance-zahranicnich-investoru-3656-cz.pdf

[3] CzechInvest, (2013). Projekt ÄWelcome Package pro investoryñ. [online]. [cit. 2014-03-27]. Dostupné z: http://www.czechinvest.org/data/files/welcome-package-3752-cz.pdf

[4] COLLINGS et al., (2010). Swimming Against the Tide: Outward Staffing Flows from Multinational Subsidiaries. Human Resource Management, vol. 49, iss.4, pp. 575-598. DOI 10.1002/hrm.20374.

[5] Deloitte corporate governance centrum, (2013). Podíl cizinc丁 ve vedení nejvhğǵch ḷ eských firem vzrostl za deset let $z p$ Yiny na více neǵ! tvrtinu. Praha: Deloitte.

[6] DVOř ÁKOVÁ, Z. et al., (2012). řízení lidských zdrojT. Praha: C.H. Beck. ISBN 978-80-7400-347-9

[7] HEENAN, A.D., PERLMUTTER, V.H., (1979). Multinational Organization Development. Pearson Addison Wesley, Reading, MA.

[8] INTERNATIONAL LABOUR ORGANIZATION, (2008). International Standard Classification of

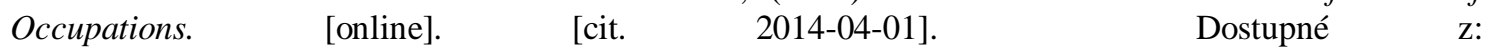
http://www.ilo.org/public/english/bureau/stat/isco/docs/resol08.pdf

[9] LOWELL, B.L., FINDLAY, A., (2001). The Migration of Highly Skilled Persons from Developing Countries: Impact and Policy Responses. International Migration Papers, iss.45, International Labour Office. [online]. [cit. 2014-04-03]. Dostupné z: http://www.ilo.org/wcmsp5/groups/public/---ed_protect/--protrav/---migrant/documents/publication/wcms_201706.pdf

[10] Ministerstvo vnitra L LR, (2012). Zelené karty. [online]. [cit. 2014-03-19]. Dostupné z: http://www.mvcr.cz/clanek/zelene-karty.aspx

[11] PERLMUTTER, V.H., (1969). The Tortuous Evolution of Multinational Enterprises. Columbia Journal of World Business, vol. 4, iss. 1, pp 9ï 18.

[12] REGETS, M.C., (2007). Research and Policy Issues in High-Skilled International Migration: A Perspective with Data from the United States. National Science Foundation, SRS 07-203 [online]. [cit. 2014-03-29]. Dostupné z: http://www.nsf.gov/statistics/srs07203/pdf/srs07203.pdf.

[13] SALT, J., (1997). International Movements of Highly Skilled. OECD Social, Employment and Migration Working Papers, no. 3. OECD Publishing. DOI 10.1787/104411065061.

[14] SCULLION, H., COLLINGS, D.G., (2006). Global Staffing. London: Routledge.

[15] TURECKIOVÁ, M., (2004). ř ízení a rozvoj lidí ve firmách. Praha: Grada.

[16] UNESCO Institute for Statistics, (2012). International Classification for Education. [online]. [cit. 201404-02]. Dostupné z: http://www.uis.unesco.org/Education/Documents/isced-2011-en.pdf

[17] VALENTA, O., (2013). Politika získávání vysoce kvalifikovaných pracovníkT ze tŚetích zemí do Leska. Ergo, vol. 8, iss. 2, pp. 18-25.

[18] VESELÁ, A., (2010). Zpráva o realizaci projektu v roce 2010 a návrh na jeho ukon! ení. Ministerstvo práce a sociálních vłýi. [online]. [cit. 2014-03-23]. Dostupné z: http://www.komora.cz/ download.aspx?dontparse $=$ true $\&$ FileID $=4526$

[19] World Bank, (2014). Migration and Remittances: Recent Developments and Outlook. [online]. [cit. 201404-12]. Dostupné z: http://siteresources.worldbank.org/INTPROSPECTS/Resources/3349341288990760745/MigrationandDevelopmentBrief22.pdf

[20] ZALETEL, P., (2006). Competing for Highly Skilled Migrants: Implications for the EU Common Approach o Temporary Economic Migration. European Law Journal, vol. 12, iss. 5, pp. 613-635. DOI 10.1111/j.1468-0386.2006.00337.x. 